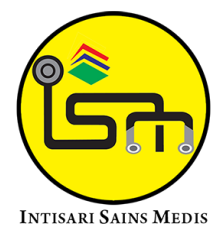

Published by Intisari Sains Medis

\section{Perbandingan kadar Thyroid Stimulating Hormone (TSH) dan kadar Free T4 (FT4) antara metode Fluorescence Immunoassay (FIA) dan metode Electrochemiluminescence Immunoassay (ECLIA) di RSUP Sanglah, Bali, Indonesia}

Ekarini Katharina Yunarti Nabu ${ }^{1 *}$, Sianny Herawati ${ }^{2}$, Ni Kadek Mulyantari², Anak Agung Wiradewi Lestari ${ }^{2}$, I Putu Yuda Prabawa ${ }^{1,2}$

\section{ABSTRACT}

Background: Diagnostic and therapeutic cases of hyperthyroidism can be identified by examining the levels of Thyroid Stimulating Hormone (TSH) and Free T4 (FT4). There are several examination methods, namely the Fluorescence Immunoassay (FIA) and the Electro-Chemiluminescence Immunoassay (ECLIA) method. This study aims to evaluate the difference in TSH and FT4 level in the FIA method and ECLIA method. Method: This study used observational analytic methods cross sectional design, with 45 samples serum patient with hyperthyroid in January-March 2019. Examine level TSH and FT4 levels with FIA methods (NANO ENTEK FREND ${ }^{\text {TM }}$ ) and ECLIA method (Cobas e601

ROCHE). Data were analyzed using SPSS version 17 for Windows.

Results: Most of the respondents were aged 25-34years (28.8\%) and female (86.7\%). There was no significant difference in the mean TSH level on examination using the ECLIA method $(0.60 \pm 0.79 \mathrm{mIU} / \mathrm{L})$ and the FIA method $(0.63 \pm 0.76 \mathrm{mlU} / \mathrm{L})(\mathrm{p}=0.639)$. In addition, there was no significant difference in FT4 both in the examination using the ECLIA method (1.67 $\pm 1.05 \mathrm{ng} /$ $\mathrm{dl})$ and the FIA method $(1.69 \pm 1.72 \mathrm{ng} / \mathrm{dl})(\mathrm{p}=0.745)$. Conclusions: There was no significant difference between TSH and FT4 in both ECLIA and FIA methods.

Keywords: TSH, FT4, FIA, ECLIA, Comparison.

Cite This Article: Nabu, E.K.Y., Herawati, S., Mulyantari, N.K., Lestari, A.A.W., Prabawa, I.P.Y. 2021. Perbandingan kadar Thyroid Stimulating Hormone (TSH) dan kadar Free T4 (FT4) antara metode Fluorescence Immunoassay (FIA) dan metode Electrochemiluminescence Immunoassay (ECLIA) di RSUP Sanglah, Bali, Indonesia. Intisari Sains Medis 12(2): 613-616. D0l: 10.15562/ism.v12i2.1062

${ }^{1}$ Program Studi Pendidikan Dokter Spesialis Patologi Klinik, Fakultas Kedokteran, Universitas Udayana, RSUP Sanglah, Bali, Indonesia;

${ }^{2}$ Departemen Patologi Klinik, Fakultas Kedokteran, Universitas Udayana, RSUP Sanglah, Bali, Indonesia;

\section{*Korespondensi:}

Ekarini Katharina Yunarti Nabu;

Program Studi Pendidikan Dokter Spesialis Patologi Klinik, Fakultas Kedokteran, Universitas Udayana, RSUP Sanglah, Bali, Indonesia;

katharinanewar15@gmail.com

Diterima: 14-06-2021

Disetujui: 18-08-2021

Diterbitkan: 31-08-2021

\title{
ABSTRAK
}

Latar Belakang: Diagnosis maupun pemantauan terapi kasus hipertiroid dapat diketahui dengan pemeriksaan kadar hormon Thyroid Stimulating Hormone (TSH) dan Free T4 (FT4). Terdapat beberapa metode pemeriksaan yaitu metode Fluorescence Immunoassay (FIA) dan metode ElectroChemiluminescence Immunoassay (ECLIA). Penelitian ini bertujuan untuk mengevaluasi perbedaan kadar TSH dan FT4 metode FIA dan metode ECLIA.

Metode: Penelitian ini menggunakan metode observasional analitik dengan desain potong lintang pada 45 sampel serum penderita hipertiroid selama periode Januari-Maret 2019. Dilakukan pemeriksaan kadar TSH dan FT4 dengan metode FIA (NANO ENTEK FREND ${ }^{\text {TM}}$ ) dan metode ECLIA (Cobas e601 Roche). Data dianalisis dengan SPSS versi 17 untuk Windows.

Hasil: Sebagian besar responden berusia 25-34 tahun (28,8\%) dan berjenis kelamin perempuan $(86,7 \%)$. Tidak terdapat perbedaan bermakna rerata kadar TSH pada pemeriksaan menggunakan metode ECLIA $(0,60 \pm 0,79 \mathrm{mIU} / \mathrm{L})$ maupun metode FIA $(0,63 \pm 0,76$ $\mathrm{mIU} / \mathrm{L})(\mathrm{p}=0,639)$. Disamping itu, tidak juga terdapat perbedaan bermakna rerata kadar FT4 baik pada pemeriksaan menggunakan metode ECLIA $(1,67 \pm 1,05$ $\mathrm{ng} / \mathrm{dl})$ maupun metode FIA $(1,69 \pm 1,72 \mathrm{ng} / \mathrm{dl})$ $(p=0,745)$. 
Kesimpulan: Tidak ada perbedaan yang bermakna antara kadar TSH dan FT4 pada metode ECLIA dan FIA.

Kata kunci: TSH, FT4, FIA, ECLIA, Perbandingan.

Sitasi Artikel ini: Nabu, E.K.Y., Herawati, S., Mulyantari, N.K., Lestari, A.A.W., Prabawa, I.P.Y. 2021. Perbandingan kadar Thyroid Stimulating Hormone (TSH) dan kadar Free T4 (FT4) antara metode Fluorescence Immunoassay (FIA) dan metode Electrochemiluminescence Immunoassay (ECLIA) di RSUP Sanglah, Bali, Indonesia. Intisari Sains Medis 12(2): 613-616. D0I: 10.15562/ism.v12i2.1062

\section{PENDAHULUAN}

Hormon tiroid mempunyai peran yang sangat penting dalam berbagai proses metabolisme dan aktivitas fisiologik pada semua sistem organ tubuh manusia. ${ }^{1}$ Kekurangan hormon maupun kelebihan hormon tiroid mengganggu proses metabolisme, aktivitas fisiologik, serta mempengaruhi pertumbuhan dan perkembangan berbagai jaringan termasuk sistem saraf dan otak. ${ }^{1}$

Hasil pemeriksaan Thyroid Stimulating Hormone (TSH) menurut Riset Kesehatan Dasar (RISKESDAS) di Indonesia tahun 2013 sebanyak 12,7\% pada laki-laki dan $14,8 \%$ perempuan memiliki kadar TSH yang rendah yang menunjukkan kecurigaan adanya hipertiroid. ${ }^{2}$ Berdasarkan kejadian tahunan telah diperkirakan kasus hipertiroid sekitar 14-50 per 100.000 orang dengan angka insiden puncaknya antara 20-50 tahun dimana risiko pada wanita diketahui lebih tinggi dibandingkan dengan pria, dengan rasio $6: 1 .^{2}$

Diagnostik maupun monitoring terapi kasus hipertiroid dapat diketahui dengan pemeriksaan kadar hormon TSH dan Free T4 (FT4). ${ }^{3}$ Dewasa ini tersedia berbagai metode pemeriksaan in-vitro yang dapat menentukan kadar hormon TSH dan FT4. Ada beberapa metode pemeriksaan TSH dan FT4 yang saat ini digunakan di klinik. Metode yang dianjurkan untuk pemeriksaan TSH dan FT4 adalah metode generasi ketiga immunometric seperti Electro-Chemiluminescence Immunoassay (ECLIA), Fluorescence Immunoassay (FIA), Chemiluminescent Immunoassay (CMIA), dan Enzyme Linked Fluorescent Assay (ELFA)., ${ }^{4,5}$ Terdapat beberapa metode yang memerlukan biaya yang relatif mahal, dan memakan waktu yang cukup lama. Sehubungan dengan hal tersebut terdapat alat yang mampu mengukur kadar TSH dan FT4 dalam waktu relatif singkat dan memerlukan volume sampel yang sedikit. Alat rapid test metode FIA (Nano ENTEK FREND $^{\mathrm{TM}}$ ) mampu mengukur kadar TSH dan FT4 dalam waktu singkat. ${ }^{6}$

Pemeriksaan kadar TSH dan FT4 di Rumah Sakit Umum Pusat Sanglah saat ini menggunakan alat dengan metode ECLIA (Cobas e601 ROCHE). Berdasarkan latar belakang tersebut maka penelitian ini bertujuan untuk mengetahui perbedaan hasil pemeriksaan kadar TSH antar metode ECLIA dan metode FIA, dan mengetahui perbedaan hasil pemeriksaan kadar FT4 pada kedua metode tersebut. Adapun manfaat dari penelitian ini adalah untuk memberikan pengetahuan pemeriksaan TSH dan FT4 dengan metode ECLIA dan metode FIA, dan secara praktis dapat digunakan sebagai salah satu alternatif metode pemeriksaan yang lebih cepat dan efektif.

\section{METODE}

Penelitian ini merupakan studi observasional analitik potong lintang (cross-sectional) di laboratorium RSUP Sanglah pada bulan Januari-Maret 2019. Teknik pengambilan sampel pada penelitian ini adalah Consecutive Sampling terhadap 45 sampel pada pasien hipertiroid. Kriteria inklusi pada penelitian ini adalah pasien hipertiroid yang bersedia berpartisipasi pada penelitian ini. Kriteria eksklusi pada penelitian ini adalah sampel pasien hemolisis, lipemik dan ikterik serta volume sampel yang kurang dari $500 \mu \mathrm{L}$. Variabel bebas pada penelitian ini adalah metode ECLIA (Cobas e601, ROCHE) dan dengan metode FIA (Nano Entek FREND $^{\mathrm{TM}}$ ). Variabel terikat adalah kadar TSH dan kadar FT4.

Alur penelitian diawali dengan pengambilan data pasien dari komputer Laboratory Information System (LIS) yang terdapat permintaan pemeriksaan TSH dan FT4, kemudian pasien yang memenuhi kriteria inklusi dilakukan pengambilan darah sebanyak $3 \mathrm{ml}$ yang ditampung dalam tabung Serum Separated Tube (SST), kemudian dilakukan sentrifugasi sehingga diperoleh serum sebanyak 100-200 $\mu \mathrm{L}$. Selanjutnya dilakukan pemeriksaan kadar TSH dan FT4 metode ECLIA, dan sisa sampel diperiksa dengan metode FIA.

Prosedur pemeriksaan kadar TSH metode ECLIA menggunakan prinsip sandwich dengan volume sampel $50 \mu \mathrm{L}$, dengan lama pemeriksaan sekitar 18 menit. Demikian halnya dengan pemeriksaan FT4 pada metode ECLIA dengan volume sampel sekitar $15 \mu \mathrm{L}$. Prinsip pemeriksaan TSH dan FT4 pada FIA menggunakan The FREND TM THYROID DUO (Free Thyroxine/ Thyroid Stimulating Hormone) yang merupakan sebuah rapid indirect competitive fluoroscence immunoassay. Volume sampel yang dibutuhkan untuk pemeriksaan sekitar $35 \mu \mathrm{L}$, dengan lama pemeriksaan 6 menit. Rentang pengukuran TSH metode FIA sebesar 0.06-25.0 mIU/L, dan rentang pengukuran kadar FT4 metode FIA sebesar 0.40-6.00 ng/dL. Rentang pengukuran kadar TSH metode ECLIA sebesar 0.01-4.20 mIU/L, dan rentang pengukuran kadar FT4 metode ECLIA adalah $0.005-100 \mathrm{ng} / \mathrm{dL}^{7,8}$ Sebelum dilakukan uji beda, dilakukan uji normalitas Saphiro-Wilk, uji homogenitas dan selanjutnya dilakukan uji Independent T-Test. Data penelitian ini diolah dengan menggunakan software IBM SPSS versi 17 untuk Windows.

\section{HASIL}

Peserta penelitian sebanyak 45 orang memiliki rentang usia 15 - 64 tahun dibagi menjadi 5 kategori usia (Tabel 1). Hasil penelitian ini menunjukkan bahwa sebagian besar responden berusia 25-34 
Tabel 1. Karakteristik Subyek Penelitian berdasarkan Umur dan Jenis Kelamin

\begin{tabular}{lcc}
\hline Karakteristik & Frekuensi & Persentase \\
\hline Usia (Tahun) & 5 & \\
$15-24$ & 13 & 11,1 \\
$25-34$ & 12 & 28,8 \\
$35-44$ & 12 & 26,7 \\
$45-54$ & 3 & 26,7 \\
$55-64$ & & 6,7 \\
Jenis Kelamin & 6 & \\
Laki-laki & 39 & 13,3 \\
Perempuan & & 86,7 \\
\hline
\end{tabular}

Tabel 2. Rerata Kadar TSH dan FT4 menggunakan metode ECLIA dan FIA

\begin{tabular}{lccc}
\hline \multirow{2}{*}{ Variabel } & \multicolumn{2}{c}{ Kelompok Penelitian } & \multirow{2}{*}{ P } \\
\cline { 2 - 3 } & ECLIA & FIA & 0,639 \\
\hline TSH (mIU/L) (rerata \pm SB $)$ & $0,60 \pm 0,79$ & $0,63 \pm 0,76$ & 0,745 \\
FT4 (ng/dl) $($ rerata \pm SB $)$ & $1,67 \pm 1,05$ & $1,69 \pm 1,72$ & 0, \\
\hline
\end{tabular}

TSH: Thyroid Stimulating Hormone; FT4: Free T4; ECLIA: Electro-Chemiluminescence Immunoassay; FIA: Fluorescence Immunoassay; ${ }^{\star}$ Uji Independent T-Test secara statistik bermakna apabila nilai p kurang dari 0,05 .

tahun $(28,8 \%)$, diikuti dengan usia $35-44$ tahun $(26,7 \%), 45-54$ tahun $(26,7 \%), 15-$ 24 tahun $(11,1 \%)$, dan $55-64$ tahun $(6,7 \%)$ (Tabel 1). Sedangkan berdasarkan jenis kelamin diketahui bahwa jenis kelamin perempuan lebih dominan (86,7\%) dibandingkan dengan laki-laki $(13,3 \%)$ (Tabel 1).

Pemeriksaan kadar TSH memperlihatkan nilai rerata pada metode ECLIA adalah sebesar $0,60 \pm 0,79 \mathrm{mIU} / \mathrm{L}$, sedangkan pada metode FIA sebesar 0,63 $\pm 0,76 \mathrm{mIU} / \mathrm{L}$. Uji Independent T-Test dilakukan karena data berdistribusi normal dan homogen dimana diperoleh nilai p sebesar 0,639 (Tabel 2) yang menunjukkan tidak terdapat perbedaan bermakna antara kadar TSH metode ECLIA dan kadar TSH metode FIA.

Pemeriksaan kadar FT4 memperlihatkan nilai rerata pada metode ECLIA sebesar 1,67 $\pm 1,05 \mathrm{mIU} / \mathrm{L}$ dan pada metode FIA sebesar $1,69 \pm 1,72 \mathrm{mIU} / \mathrm{L}$ (Tabel 2). Uji Independent T-Test dilakukan karena data berdistribusi normal dan homogen dimana diperoleh nilai $p$ sebesar 0,745 (Tabel 2) yang menunjukkan tidak terdapat perbedaan bermakna antara kadar FT4 menggunakan metode ECLIA dan kadar FT4 metode FIA.

\section{PEMBAHASAN}

Pemeriksaan TSH dan FT4 merupakan diagnosis awal untuk mendeteksi kelainan fungsi hormon tiroid. Sebanyak 45 sampel pasien yang memenuhi kriteria inklusi penelitian dengan jenis kelamin perempuan lebih banyak daripada lakilaki (6:1) dan ditemukan terbanyak pada rentang usia 25-54 tahun. Hal ini sesuai dengan data RISKESDAS (riset kesehatan dasar) yang menyatakan prevalensi penyakit hipertiroid yang paling sering terjadi pada usia 25-54 tahun. ${ }^{2}$ Prevalensi ini sesuai dengan penelitian yang dilakukan oleh Kahaly GJ et al., yang menemukan kejadian hipertiroid lebih pada perempuan dengan rentang usia 3060 tahun. ${ }^{9}$ Sama halnya dengan penelitian oleh Carmona CAC et al., di Colombia bahwa kejadian hipertiroid lebih sering terjadi pada perempuan dengan rentang usia 20-60 tahun. ${ }^{10}$

Pada penelitian ini alat otomatis Nano Entek FREND ${ }^{\mathrm{TM}}$ dengan metode FIA tidak memiliki perbedaan bermakna jika dibandingkan dengan metode ECLIA pada alat cobas e601 ROCHE untuk kadar TSH dan FT4. Hasil penelitian ini sejalan dengan penelitian oleh Pramila $\mathrm{K}$ et al., yang membandingkan kadar TSH antara metode Enzyme Linked Fluorescent Assay (ELFA) dan Enzyme Linked Immunosorbent Assay (ELISA) yang menyatakan kadar TSH pada pasien hipertiroid tidak berbeda bermakna antara kedua metode. ${ }^{11}$ Hal ini juga sesuai dengan penelitian yang dilakukan oleh Park HS et al., yang membandingkan pemeriksaan kadar TSH dan FT4 metode FIA dan metode Chemiluminescent Microparticle Immunoassay (CMIA) ditemukan juga hasil yang tidak berbeda bermakna dan dikatakan Nano Entek FREND ${ }^{\mathrm{TM}}$ memiliki kinerja yang memuaskan pada laboratorium klinik. ${ }^{6}$ Pemeriksaan TSH dan FT4 dengan metode FIA (Nano Entek FREND ${ }^{\mathrm{TM}}$ ) memiliki batas deteksi terendah yang cukup baik dengan kadar TSH 0,06 mIU/L dan kadar FT4 0,4 ng/ $\mathrm{dL}$, sesuai dengan yang ditetapkan Clinical and Laboratory Standard Institute (CLSI). ${ }^{12}$ Oleh karena itu dapat disimpulkan bahwa pemeriksaan TSH dan FT4 dengan metode FIA dapat digunakan untuk diagnosis maupun pemantauan terapi pusat-pusat kesehatan yang tidak memiliki autoanalyzer dengan jumlah sampel yang sedikit dan waktu yang lebih cepat.

\section{SIMPULAN}

Berdasarkan hasil penelitian didapatkan bahwa tidak terdapat perbedaan bermakna kadar TSH dan FT4 antara metode ECLIA maupun dengan menggunakan FIA.

\section{KONFLIK KEPENTINGAN}

Tidak terdapat konflik kepentingan dalam penulisan laporan penelitian ini.

\section{ETIKA PENELITIAN}

Penelitian ini telah mendapatkan persetujuan etik dari Komisi Etik, Fakultas Kedokteran, Universitas Udayana, RSUP Sanglah, Bali, Indonesia sebelum penelitian berjalan.

\section{PENDANAAN}

Penulis bertanggung jawab terhadap pendanaan penelitian ini tanpa melibatkan pihak sponsor, beasiswa, ataupun sumber pendanaan lainnya.

\section{KONTRIBUSI PENULIS}

Seluruh penulis memiliki kontribusi yang sama dalam penulisan laporan penelitian ini baik dari tahap penyusunan kerangka konsep, pengumpulan data, analisis data penelitian, hingga interpretasi hasil dalam bentuk laporan penelitian. 


\section{DAFTAR PUSTAKA}

1. Stathatos N. Thyroid physiology. Med Clin North Am. 2012;96(2):165-173.

2. INFODATIN. Situasi dan Analisis Penyakit Tiroid. Pusat Data dan Informasi Kementerian Kesehatan RI. 2015.

3. Kravets I. Hyperthyroidism: Diagnosis and Treatment. Am Fam Physician. 2016;93(5):363370.

4. Liewendahl K. Assessment of thyroid status by laboratory methods: developments and perspectives. Scand J Clin Lab Invest Suppl. 1990;201:83-92.

5. Kazerouni F, Amirrasouli H. Performance characteristics of three automated immunoassays for thyroid hormones. Caspian J Intern Med. 2012;3(2):400-104.
6. Park HS, Yoo J, Lee H, Choi AR, Ryu J, Park $\mathrm{KH}$, et al. Analytical Evaluation of Portable and Simple FREND Fluorescent Immunoassay for Rapid Quantification of Thyroid-Stimulating Hormone and Free Thyroxine. Clin Lab. 2016;62(12):2455-2460.

7. Nano Entek. Insert kit FREND ${ }^{\mathrm{TM}}$ thyroid DUO Korea. 2018. [Available at www.nanoentek. com]

8. Roche. Elecsys Brahms TSH and FT4 Diagnostics Roche. 2018. [Available at http://elabdoc.roche.com.Germany]

9. Kahaly GJ, Bartalena L, Hegedüs L, Leenhardt L, Poppe K, Pearce SH. 2018 European Thyroid Association Guideline for the Management of Graves' Hyperthyroidism. Eur Thyroid J. 2018;7(4):167-186.

10. Carmona CAC, Bedoya PA, Acevedo JB, Arias JAC. Prevalence of Thyroid Disorders in an Institution Providing Health Services in Medellin-Colombia. Translational Biomedicine. 2018;9(2):1-6.

11. Pramila K, Gopinath P, Shanthi KM, Divya M. Analytical Sensitivity of TSH Assays by ELISA and ELFA. National Journal of Basic Medical Sciences. 2016;6(4):157-162.

12. Wang D, Yu S, Ma C, Li H, Qiu L, Cheng $\mathrm{X}$, et al. Reference intervals for thyroidstimulating hormone, free thyroxine, and free triiodothyronine in elderly Chinese persons. Clin Chem Lab Med. 2019;57(7):1044-1052.

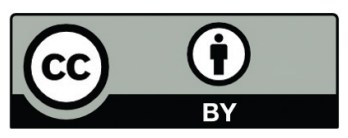

This work is licensed under a Creative Commons Attribution 